\title{
Lymphocyte subset analysis to evaluate the prognosis of HIV-negative patients with pneumocystis pneumonia
}

\author{
Fan Jin ${ }^{1}$, Jing Xie ${ }^{1}$ and Huan-ling Wang ${ }^{1,2^{*}}$
}

\begin{abstract}
Objectives: We analysed the peripheral blood lymphocyte subsets of human immunodeficiency virus (HIV)negative patients infected with pneumocystis pneumonia (PCP) to determine the relationships between the levels of different types of lymphocytes and the prognosis of patients.

Methods: We retrospectively reviewed HIV-negative patients with PCP diagnosed in our department. All the eligible patients underwent lymphocyte subset analysis on admission.

Results: A total of 88 HIV-negative PCP patients were enrolled in the study. In univariate analyses, low CD4+ T cell count, low CD8+ T cell count, and low natural killer cell (NK cell) count were associated with higher in-hospital mortality. CD8+ T cell count $\leq 300 / \mu \mathrm{L}$ was found to be an independent risk factor for poor prognosis in multivariate logistical regression analysis ( $p=0.015, \mathrm{OR}=11.526,95 \% \mathrm{Cl}=1.597-83.158$ ). Although low CD4+ T cell and NK cell counts were not independent risk factors, the mortality rates of PCP patients decreased as the CD4+ T cell and NK cell counts increased.

Conclusion: The immune process of Pneumocystis jirovecii infection is complex but important. We propose that lymphocyte subsets could give clinicians a better understanding of patient immune status, helping with the early identification of potentially lethal infections and treatment decision making, such as adjusting the immunosuppressive regimen and choosing an appropriate patient monitoring level.
\end{abstract}

\section{Introduction}

Pneumocystis pneumonia (PCP) is a life-threatening interstitial pneumonia caused by Pneumocystis jirovecii in immunocompromised patients $[1,2]$. PCP has long been known for its high prevalence in acquired immunodeficiency deficiency syndrome (AIDS) patients [3], but the incidence of PCP in human immunodeficiency virus (HIV)-positive patients has been decreased largely due to the broader use of highly active antiretroviral therapy

\footnotetext{
*Correspondence: wanghuanling@pumch.cn

'Department of Infectious Diseases, Peking Union Medical College Hospital, Chinese Academy of Medical Sciences \& Peking Union Medical College, No.1 Shuaifuyuan, Wangfujing, Dongcheng District, Beijing 100730, China

${ }^{2}$ Clinical Pharmacology Research Center, Peking Union Medical College Hospital, Chinese Academy of Medical Sciences \& Peking Union Medical College, Beijing 100730, China
}

(HAART) and trimethoprim-sulfamethoxazole (TMP/ SMZ) prophylaxis when the CD4+ T cell count is $<200 /$ $\mu \mathrm{L}[4,5]$. Recently, PCP has been frequently diagnosed in HIV-negative patients, as immunosuppressive regimens are being increasingly used in a wide range of patients. The most common underlying conditions of PCP in non-HIV-infected patients are haematological malignancies, followed by solid tumours, autoimmune diseases, solid organ transplantation, etc. $[6,7]$. The mortality rate among patients with PCP in this population is $30-60 \%$ [6]. HIV-negative PCP patients are more likely to have acute onset, more severe symptoms, and worse prognosis than HIV-positive patients [6]. Identifying potential prognostic factors in PCP patients could

(c) The Author(s). 2021 Open Access This article is licensed under a Creative Commons Attribution 4.0 International License, which permits use, sharing, adaptation, distribution and reproduction in any medium or format, as long as you give appropriate credit to the original author(s) and the source, provide a link to the Creative Commons licence, and indicate if changes were made. The images or other third party material in this article are included in the article's Creative Commons licence, unless indicated otherwise in a credit line to the material. If material is not included in the article's Creative Commons licence and your intended use is not permitted by statutory regulation or exceeds the permitted use, you will need to obtain permission directly from the copyright holder. To view a copy of this licence, visit http://creativecommons.org/licenses/by/4.0/. The Creative Commons Public Domain Dedication waiver (http://creativecommons.org/publicdomain/zero/1.0/) applies to the data made available in this article, unless otherwise stated in a credit line to the data. 
help clinicians choose appropriate treatment strategies and monitoring levels.

The major portion of the PCP process results from the host inflammatory response to apparent infection with $P$. jirovecii rather than direct tissue damage from $P$. jirovecii itself $[8,9]$. Because PCP is a type of opportunistic infection (OI), lymphocyte subsets can be used as important indicators of the immune function of the body and can help with the clinical diagnoses of some infectious diseases, which is of great significance for analysing the pathogenesis, observing the curative effect, and predicting the prognosis [10]. T cells are known to be involved in the suppression of the autoimmune response and hyperinflammation mediated by $\mathrm{CD} 4+\mathrm{T}$ cells [11]. $B$ cells and NK cells are critical for an effective CD4+ T cell response that can control Pneumocystis infection [12]. In this article, we analysed the peripheral blood lymphocyte subsets of HIV-negative PCP patients to determine the influence of $\mathrm{T}$ lymphocyte, $\mathrm{B}$ lymphocyte and natural killer cell (NK cell) counts on prognosis.

\section{Material and methods}

\section{Patients selection}

We carried out an observational retrospective study from 2012 to 2018 in the Peking Union Medical College Hospital (PUMCH), a 2000-bed tertiary care centre in Beijing, China. PCP was diagnosed based on consensus guidelines, which require either $P$. jirovecii microorganisms in respiratory samples by microscopic examination or both a positive polymerase chain reaction (PCR) test for $P$. jirovecii DNA in respiratory samples and an increased level of serum 1,3- $\beta$-D-glucan ( $\beta D G$ ) [13]. Patients were eligible for enrolment if they fulfilled all the following criteria: (1) being older than 18 years of age; (2) being HIV negative; and (3) undergoing lymphocyte subset analysis after presenting with infection on admission. The follow-up time was more than 3 months. We excluded patients who were lost to follow-up or had incomplete data.

This retrospective study was reviewed and approved by the Institutional Review Board (IRB) of PUMCH. Researchers did not interfere with the treatment plan of patients, and they prevented the information of patients from being disclosed. The study met the IRB's minimal risk waiver criteria; therefore, the requirement to obtain informed consent from each patient was waived.

\section{Technical information}

We used primers to amplify the major surface glycoprotein (MSG) gene of $P$. jirovecii by PCR. The primer sequences for amplifying MSG were MSG-fw, 5'CTTAAAATAAATAATCAGACTATGTGCGATAAG3', and MSG-rv, 5'-GGAGCTTTAATTACTTTTTTCT GGC-3'. A dual-labelled fluorescence resonance energy transfer (FRET) hybridization probe (MSG-probe 5' FAM-TAGATAGTCGAAAGGGAAA-MGE-3') was used for detection. The cycle threshold $(\mathrm{Ct})$ value was checked for all positive samples. This was defined as the replication cycle number at which the fluorescence generated within a reaction crossed the fluorescence threshold. A lower $\mathrm{Ct}$ value correlates with a higher fungal burden. According to a previous study, a qPCR Ct value above 35 correlates with a clinically low fungal burden and negligible colonization [14]. A positive qPCR result in our study was defined as a Ct value $\leq 37$.

Lymphocyte subset analysis was performed in the clinical haematology laboratory by trained personnel using a FACScan flow cytometer (Beckman-Coulter, USA). The monoclonal antibodies used in this study (purchased from Beckman-Coulter and Immunotech, USA) included PEcy5-CD4/PE- CD8/FITC-CD3 (CD4+/CD8 + T cell count) and PEcy5-CD19/PE- CD16 CD56/FITC-CD3 (B/ NK cell count).

\section{Data collection}

All medical records were reviewed retrospectively using a standardized research protocol. The chart review included demographic characteristics, underlying diseases, laboratory data, presence of co-infection, immunosuppressive treatments, the dosage and exposure time of corticosteroid (CS) treatment, and the time from symptom onset to anti-PCP treatments. Additionally, the need for intensive care unit (ICU) admission and mechanical ventilation (MV) and the clinical outcomes were recorded for all patients. Co-infections, such as with bacteria, Candida, Aspergillus, cytomegalovirus, and Epstein-Barr virus, were also evaluated. Survival was defined as being alive 3 months after symptom onset.

\section{Statistical analysis}

Categorical variables were analysed by the chi-square test or Fisher's exact test, as appropriate. Continuous variables were analysed using the Wilcoxon signed-rank test. In order to determine the best critical threshold of these cell counts for predicting the prognosis, we constructed receiver operating characteristic (ROC) curves to investigate the predictors of in-hospital mortality. The ROC curve showed the tradeoff between true detections and false detections in univariate analysis in predicting the prognosis of PCP. On each ROC curve, we calculated the point with the largest Youden index (Youden index $=$ sensitivity + specificity -1 ) as the cut-off threshold. To identify predictors of in-hospital mortality or survival, we applied univariate and multivariate logistical regression analyses and Cox regression hazards models. Consequently, both odds ratio (OR) and hazard ratio (HR) estimates are reported. The 95\% confidence intervals (CIs) were calculated. In addition, we calculated the 
time from symptom onset to all-cause mortality from multivariable Cox regression models. All statistical analyses were performed using SPSS 22.0 (SPSS Inc., Chicago, IL, USA). $P$-values $<0.05$ were considered statistically significant.

\section{Results}

\section{Baseline patient characteristics}

A total of 180 HIV-negative patients had positive PCR and/or Grocott's methenamine silver (GMS) staining results on sputum or bronchoalveolar lavage (BAL). A total of 88 patients met the inclusion criteria (Table 1). The median age of the patients was 57 years old, and $42 \%$ of them were male. The most common underlying disease was autoimmune disease $(n=61,69 \%)$; others included haematological disorders, haematologic malignancies, solid cancers, severe combined immunodeficiency, idiopathic pulmonary fibrosis, and solid organ transplantation. Thirty-four percent of the patients had underlying lung diseases, such as interstitial lung disease caused by autoimmune diseases, lung metastasis caused by solid tumours, and idiopathic pulmonary fibrosis. Immunosuppressive regimens consisted mainly of a combination of CS and immunosuppressive drugs. The median CS exposure time of patients was 3 months (interquartile range 2 to 42 months). The majority of patients were complicated with viral infection (63\%), followed by bacterial (30\%) and fungal infections (18\%). Compared with the normal ranges, patients with PCP had significantly low immune cell counts (including CD19+ B cells, CD16 + CD56+ NK cells, and CD3+ T cells) and a low ratio of $\mathrm{CD} 4+/ \mathrm{CD} 8+$ cells (median ratio was 0.6).

\section{Clinical parameters and outcomes}

As shown in Tables 1, 44\% $(n=39)$ of HIV-negative patients infected with PCP died within 3 months after symptom onset. No differences were noted in age, sex, previous use of chemotherapy, immunosuppressive regimen, dosage or exposure time of CS treatment, coinfections (bacterial, viral, or fungal), or treatment delay (symptom onset to treatment) between survivors and non-survivors. Compared with survivors, non-survivors had significantly lower albumin levels $(p=0.027)$, higher LDH levels $(p<0.001)$, and higher demand for mechanical ventilation $(p<0.001)$. More non-survivors had underlying lung diseases $(p=0.033)$. As for lymphocyte subsets, non-survivors had a significantly lower NK cell count ( 22 vs. 50 cell $/ \mu \mathrm{L}, p=0.014$ ), lower $\mathrm{CD} 4+\mathrm{T}$ cell count (81 vs. 149 cell $/ \mu \mathrm{L}, p=0.004$ ) and lower CD8+ T cell count ( 114 vs. 239 cell $/ \mu \mathrm{L}, p<0.001)$. There was no significant difference in $\mathrm{B}$ cell count between survivors and non-survivors (55 vs. $34 \mathrm{cell} / \mu \mathrm{L}, p=0.346$ ).

\section{Lymphocyte subset analysis and prognosis}

Compared with survivors in the univariate analysis, the non-survivors had lower CD4+ T, CD8+ T, and NK cell counts (Table 2). As shown in Fig. 1, the area under the curve (AUC) of CD8+ T cell count was $0.728(p<0.001)$, indicating that $\mathrm{CD} 8+\mathrm{T}$ cell count was an important predictor of in-hospital mortality. The optimal cut-off for CD8 $+\mathrm{T}$ cell count was determined to be $300 / \mu \mathrm{L}$, and the specificity and sensitivity were 0.95 and 0.47 , respectively. The area under the CD4+ T cell count curve $(p=0.020)$ and the area under the NK cell count curve $(p=0.005)$ were slightly smaller. The optimal cut-off for CD4+ T cell count was determined to be $100 / \mu \mathrm{L}$, with a specificity and sensitivity of 0.71 and 0.67 , respectively. The optimal cut-off for NK cell count was determined to $25 / \mu \mathrm{L}$, with a specificity and sensitivity of 0.68 and 0.79 .

The 3-month mortality rates of patients with different CD4+ T, CD8+ T, and NK cell counts are shown in Fig. 2. We found that the mortality rates of patients decreased sequentially in the four $\mathrm{CD} 4+\mathrm{T}$ cell count ranges of $0-100 / \mu \mathrm{L}, 101-200 / \mu \mathrm{L}, 201-300 / \mu \mathrm{L}$, and > $300 / \mu \mathrm{L}$, being equal to $63,38,33$ and $18 \%$, respectively. Similarly, the mortality rates of patients with NK cell counts of $0-25 / \mu \mathrm{L}, 26-50 / \mu \mathrm{L}, 51-100 / \mu \mathrm{L}$, and $>100 / \mu \mathrm{L}$ were $65,40,27$ and $26 \%$. The mortality rates were almost the same between patients with $\mathrm{CD} 8+\mathrm{T}$ cell counts of $0-100 / \mu \mathrm{L}, 101-200 / \mu \mathrm{L}$, and $201-300 / \mu \mathrm{L}$, but for patients with CD8+ T cell count $>300 / \mu \mathrm{L}$, the mortality rate dropped by more than $40 \%$.

\section{Independent predictors of mortality in PCP patients}

Prognostic factors of 3-month mortality were explored through logistic regression. Table 2 shows the results of the multivariate analysis. In the multivariate analysis, corrections were made for underlying lung disease, need for mechanical ventilation, and $\mathrm{CD} 4+\mathrm{T}, \mathrm{CD} 8+\mathrm{T}$, and NK cell counts. In HIV-negative patients with PCP, the presence of a CD8 $+\mathrm{T}$ cell count $\leq 300 / \mu \mathrm{L} \quad(p=0.015$, $\mathrm{OR}=11.526,95 \% \mathrm{CI}=1.597-83.158)$ and a demand for mechanical ventilation $(p<0.001, \mathrm{OR}=33.578,95 \% \mathrm{CI}=$ 8.056-139.950) were independent predictors of 3-month all-cause mortality.

We next performed a Cox regression hazards model to further understand the interdependence of CD8+ T cell count as a determinant of 3-month mortality. The survival probability curve is shown in Fig. 3 . The results further confirmed that a low CD8+ T cell count was significantly associated with high mortality $(p=0.001, \mathrm{HR}=$ 6.799, $95 \% \mathrm{CI}=2.090-22.121$ ).

\section{Discussion}

In this study, all 88 HIV-negative patients with PCP had long-term and varying degrees of 
Table 1 Clinical characteristics, management, and outcomes of in HIV negative patients with PJP

\begin{tabular}{|c|c|c|c|c|}
\hline & $\begin{array}{l}\text { Total } \\
(n=88)\end{array}$ & $\begin{array}{l}\text { Survivors } \\
(n=49)\end{array}$ & $\begin{array}{l}\text { Non-survivors } \\
(\mathrm{n}=39)\end{array}$ & P-value \\
\hline \multicolumn{5}{|l|}{ Demographics } \\
\hline Age, years & $58(42-64)$ & $58(48-64)$ & $55(40-63)$ & 0.559 \\
\hline Sex (male) & $37(42 \%)$ & $22(45 \%)$ & 15 (39\%) & 0.543 \\
\hline Underlying lung disease & $30(34 \%)$ & $12(24 \%)$ & $18(49 \%)$ & 0.033 \\
\hline \multicolumn{5}{|l|}{ Immunosuppressive conditions } \\
\hline Autoimmune diseases & $61(69 \%)$ & $32(66 \%)$ & $29(74 \%)$ & 0.360 \\
\hline Hematologic disorder & $6(7 \%)$ & $4(8 \%)$ & $2(5 \%)$ & 0.609 \\
\hline Hematologic malignancy & $5(6 \%)$ & $1(2 \%)$ & $4(10 \%)$ & 0.098 \\
\hline Solid cancer & $8(9 \%)$ & $5(10 \%)$ & $3(8 \%)$ & 0.684 \\
\hline Other disease ${ }^{a}$ & $8(9 \%)$ & $7(14 \%)$ & $1(3 \%)$ & 0.057 \\
\hline \multicolumn{5}{|l|}{ Laboratory values on admission } \\
\hline Albumin, g/L & $27(24-31)$ & $29(25-32)$ & $26(24-29)$ & 0.027 \\
\hline $\mathrm{LDH}, \mathrm{U} / \mathrm{L}$ & $566(422-718)$ & $460(332-612)$ & $656(557-946)$ & $<0.001$ \\
\hline $\mathrm{PaO} 2, \mathrm{mmHg}$ & $53(46-59)$ & $56(47-61)$ & $51(39-59)$ & 0.174 \\
\hline $\mathrm{D}(\mathrm{A}-\mathrm{a}) \mathrm{O} 2, \mathrm{mmHg}$ & $60(52-68)$ & $60(53-66)$ & $61(52-69)$ & 0.157 \\
\hline Creatinine, mg/d & $68(53-110)$ & 65 (53-94) & $69(54-115)$ & 0.146 \\
\hline $\mathrm{CRP}, \mathrm{mg} / \mathrm{dL}$ & $12(6-80)$ & $9(5-63)$ & $21(6-114)$ & 0.629 \\
\hline \multicolumn{5}{|l|}{ Flow cytometry on admission ${ }^{b}$} \\
\hline Lymphocyte count $(\times 106 \mathrm{~g} / \mathrm{L})$ & $360(237-711)$ & $499(280-1032)$ & $301(160-406)$ & 0.162 \\
\hline CD19+ B, cell/ $/ \mathrm{L}$ & $36(11-102)$ & $55(18-141)$ & $34(8-64)$ & 0.346 \\
\hline CD16 + CD56+ NK, cell/pL & $34(14-73)$ & $50(26-83)$ & $22(7-46)$ & 0.014 \\
\hline CD3+ T, cell/ $\mu \mathrm{L}$ & $297(174-662)$ & $517(234-871)$ & $209(138-330)$ & $<0.001$ \\
\hline $\mathrm{CD} 4+\mathrm{T}$, cell/ $\mu \mathrm{L}$ & $120(48-232)$ & $149(82-314)$ & $81(35-145)$ & 0.004 \\
\hline $\mathrm{CD} 8+\mathrm{T}$, cell/ $\mu \mathrm{L}$ & $151(78-356)$ & $239(101-455)$ & $114(59-204)$ & $<0.001$ \\
\hline CD4+/CD8+ ratio & $0.53(0.31-1.38)$ & $0.6(0.3-1.4)$ & $0.6(0.4-1.5)$ & 0.971 \\
\hline \multicolumn{5}{|l|}{ Immuosuppressive conditions } \\
\hline CS exposure time, month & $3(2-42)$ & $4(2-22)$ & $3(2-53)$ & 0.490 \\
\hline $\mathrm{CS} \leq 40 \mathrm{mg} / \mathrm{d}$ & $56(64 \%)$ & $30(61 \%)$ & $26(67 \%)$ & 0.598 \\
\hline $500 \mathrm{mg} / \mathrm{d}>\mathrm{CS} \geq 80 \mathrm{mg} / \mathrm{d}$ & $5(6 \%)$ & $2(4 \%)$ & $3(8 \%)$ & 0.467 \\
\hline $\mathrm{CS} \geq 500 \mathrm{mg} / \mathrm{d}$ & $8(9 \%)$ & $2(4 \%)$ & $6(15 \%)$ & 0.067 \\
\hline \multicolumn{5}{|c|}{ Non-steroidal immunosuppressive therapy } \\
\hline Cyclophosphamide & $33(38 \%)$ & $17(35 \%)$ & $16(41 \%)$ & 0.542 \\
\hline Methotrexate & $9(10 \%)$ & $4(8 \%)$ & $5(13 \%)$ & 0.474 \\
\hline Mycophenolate mofetil & $8(9 \%)$ & $6(12 \%)$ & $2(5 \%)$ & 0.249 \\
\hline Azathioprine & $2(2 \%)$ & $1(2 \%)$ & $1(3 \%)$ & 0.870 \\
\hline Leflunomide & $8(9 \%)$ & $4(8 \%)$ & $4(10 \%)$ & 0.734 \\
\hline Tacrolimus & $5(6 \%)$ & $2(4 \%)$ & $3(8 \%)$ & 0.467 \\
\hline CS + immunosuppressive drug & $52(59 \%)$ & $27(55 \%)$ & $25(64 \%)$ & 0.394 \\
\hline Chemotherapy & $14(16 \%)$ & $6(12 \%)$ & $8(21 \%)$ & 0.292 \\
\hline \multicolumn{5}{|l|}{ Imaging manifestations } \\
\hline Ground glass opacity & $69(78 \%)$ & $38(79 \%)$ & $31(84 \%)$ & 0.826 \\
\hline Consolidations & $20(23 \%)$ & $10(21 \%)$ & $10(27 \%)$ & 0.561 \\
\hline
\end{tabular}


Table 1 Clinical characteristics, management, and outcomes of in HIV negative patients with PJP (Continued)

\begin{tabular}{|c|c|c|c|c|}
\hline & $\begin{array}{l}\text { Total } \\
(n=88)\end{array}$ & $\begin{array}{l}\text { Survivors } \\
(n=49)\end{array}$ & $\begin{array}{l}\text { Non-survivors } \\
(\mathrm{n}=39)\end{array}$ & P-value \\
\hline Bacterial & $26(30 \%)$ & $13(27 \%)$ & $12(31 \%)$ & 0.661 \\
\hline Viral & $55(63 \%)$ & $30(61 \%)$ & $25(64 \%)$ & 0.780 \\
\hline Fungal & $16(18 \%)$ & $10(20 \%)$ & $6(15 \%)$ & 0.544 \\
\hline \multicolumn{5}{|l|}{ Clinical progression } \\
\hline Symptoms onset to treatment, days & $7(4-15)$ & $8(5-16)$ & $7(3-12)$ & 0.359 \\
\hline Mechanical ventilation & $44(50 \%)$ & $10(20 \%)$ & $34(87 \%)$ & $<0.001$ \\
\hline
\end{tabular}

${ }^{a}$ Others: Severe combined immunodeficiency, idiopathic pulmonary fibrosis and solid organ transplantation

${ }^{b}$ Normal reference value: CD19+ B 180-324 cell/ $\mu \mathrm{L}$, CD16 + CD56+ NK 175-567 cell/ $\mu \mathrm{L}, \mathrm{CD} 3+\mathrm{T} 1185-1901$ cell/ $\mu \mathrm{L}, \mathrm{CD} 4+\mathrm{T} 561-1137$ cell/ $\mu \mathrm{L}, \mathrm{CD} 8+\mathrm{T} 404-754$ cell/ $\mu \mathrm{L}$, and $\mathrm{CD} 4+/ \mathrm{CD} 8+$ ratio $0.95-2.13$

Data are presented as median (interquartile range) and $\mathrm{n}(\%)$

immunosuppression, mostly manifesting as diffuse lymphocyte depletion. Dichotomizing patients around the threshold calculated from ROC analysis, we identified a CD8+ T cell count $<300 / \mu \mathrm{L}$ as an independent risk factor for death in PCP patients. Additionally, the HR of CD8+ T cell count $<300 / \mu \mathrm{L}$ was 6.799 , which was associated with 3-month mortality. Although low CD4+ T cell and NK cell counts were not independent risk factors for death, the mortality rates of $\mathrm{PCP}$ patients decreased sequentially with increasing CD4+ T cell and NK cell counts.
In the HIV epidemic of the 1980s, PCP was known as the most common OI among AIDS patients. In recent years, immunosuppressive therapy and biological agents, especially when used in combination, have increased the risk of infection by opportunistic pathogens such as $P$. jiroveci [15]. Many large retrospective cohort studies have shown that a low $\mathrm{CD} 4+\mathrm{T}$ cell count is a risk factor for death in HIV-positive patients infected with PCP [16-20], and lymphopenia is a poor prognostic factor in HIV-negative patients with PCP infection [21]. In animals without HIV infection, an inverse relationship

Table 2 Characteristics associated with mortality in a univariate and multivariate analysis in HIV negative patients with PJP

\begin{tabular}{|c|c|c|c|c|}
\hline \multirow[t]{2}{*}{ Characteristics } & \multicolumn{2}{|l|}{ Univariate analysis } & \multicolumn{2}{|l|}{ Multivariate analysis } \\
\hline & OR $(95 \% \mathrm{Cl})$ & $P$-value & OR $(95 \% \mathrm{Cl})$ & $P$-value \\
\hline \multicolumn{5}{|c|}{ Underlying lung disease } \\
\hline no & 1 & & 1 & \\
\hline yes & $2.643(1.068-6.538)$ & 0.035 & $2.134(0.501-9.089)$ & 0.305 \\
\hline \multicolumn{5}{|l|}{ Albumin } \\
\hline$\geq 30$ & 1 & & & \\
\hline$<30$ & $2.500(0.981-6.371)$ & 0.055 & & \\
\hline \multicolumn{5}{|l|}{$\mathrm{LDH}, \mathrm{U} / \mathrm{L}$} \\
\hline$<600$ & 1 & & & \\
\hline$\geq 600$ & $2.196(0.928-5.198)$ & 0.074 & & \\
\hline \multicolumn{5}{|l|}{ CD4+ T, cell/ $\mu \mathrm{L}$} \\
\hline$\geq 100$ & 1 & & 1 & \\
\hline$<100$ & $3.793(1.341-10.729)$ & 0.012 & $0.255(0.040-1.646)$ & 0.151 \\
\hline \multicolumn{5}{|l|}{$\mathrm{CD} 8+\mathrm{T}$, cell/ $\mu \mathrm{L}$} \\
\hline$\geq 300$ & 1 & & 1 & \\
\hline$<300$ & $10.615(2.880-39.130)$ & $<0.001$ & $11.526(1.597-83.158)$ & 0.015 \\
\hline \multicolumn{5}{|c|}{ CD16 + CD56+ NK, cell/ $\mu \mathrm{L}$} \\
\hline$\geq 25$ & 1 & & 1 & \\
\hline$<25$ & 3.990 (1.609-9.893) & 0.003 & $2.168(0.561-8.379)$ & 0.262 \\
\hline \multicolumn{5}{|c|}{ Mechanical ventilation } \\
\hline no & 1 & & 1 & \\
\hline yes & $26.520(8.248-85.265)$ & $<0.001$ & $33.578(8.056-139.950)$ & $<0.001$ \\
\hline
\end{tabular}



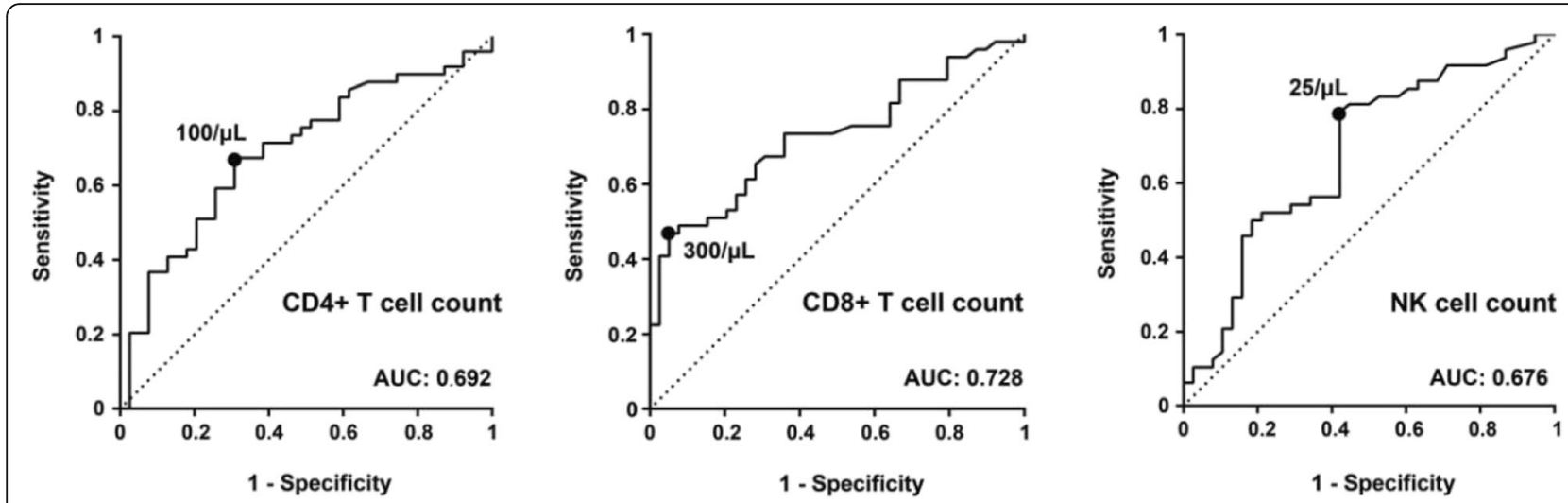

Fig. 1 ROC curves for the predictors of in-hospital mortality for CD4+ T, CD8+ T, and NK cell counts

between the $P$. carinii burden and the level of circulating CD4+ or CD8+ $\mathrm{T}$ lymphocytes has been found [22], which demonstrated the impact of immune system status on susceptibility to opportunistic pathogens. However, the prognostic value of lymphocyte subsets in HIVnegative PCP patients remains unclear. One small retrospective study revealed that CD $4+\mathrm{T}$ cell count $<200 / \mu \mathrm{L}$ in kidney transplant recipients was a poor prognostic factor for PCP infection [23], and another showed that CD8 $+\mathrm{T}$ cell count $<160 / \mu \mathrm{L}$ was strongly associated with mortality in autoimmune disease patients with $\mathrm{PCP}$ [24]. However, we identified CD8 $+\mathrm{T}$ cell count $<300$ / $\mu \mathrm{L}$ as an independent risk factor for death in HIVnegative PCP patients. In addition, NK cell count was included in such an analysis for the first time.

As a threshold for predicting mortality, the sensitivity of CD8+ T cell count $<300 / \mu \mathrm{L}$ was low in our analysis. This means that other values below this threshold may also be correlated with poor prognosis. As shown in Fig. 2 , the mortality rates of patients with $\mathrm{CD} 8+\mathrm{T}$ cell counts ranging from 0 to $100 / \mu \mathrm{L}$ and $101-200 / \mu \mathrm{L}$ were very close to that of the $201-300 / \mu \mathrm{L}$ group. The mortality of the patients was significantly reduced when the CD8+ T cell count was $>300 / \mu \mathrm{L}$, which demonstrates the high specificity of this threshold. We suggest paying more attention to patients with $\mathrm{CD} 8+\mathrm{T}$ cell counts below $300 / \mu \mathrm{L}$.

The pathogenesis and prognosis of opportunistic infection are closely related to immune status, and the importance of lymphocytes in combatting $P$. jirovecii infection has been recognized. Lymphocytes participate in host defence by regulating other immune cells, producing antibodies against pathogens (B cells) and killing organisms (cytotoxic CD8+ T cells and NK cells) [25]. $\mathrm{CD} 4+\mathrm{T}$ cells can promote the proliferation and differentiation of $\mathrm{B}$ cells, $\mathrm{T}$ cells, and other immune cells; coordinate the interaction between immune cells; and play a central role in coordinating host defence mechanisms. $\mathrm{CD} 8+\mathrm{T}$ cells include inhibitory $\mathrm{T}$ cells and killer $\mathrm{T}$ cells [26]. If the inflammatory response is driven by $\mathrm{CD} 4+\mathrm{T}$ cells without sufficient inhibitory activity from CD8+ T cells, it will cause an effective but excessive inflammatory response similar to immune restoration disease (IRD), and the elimination of pathogens will incur severe

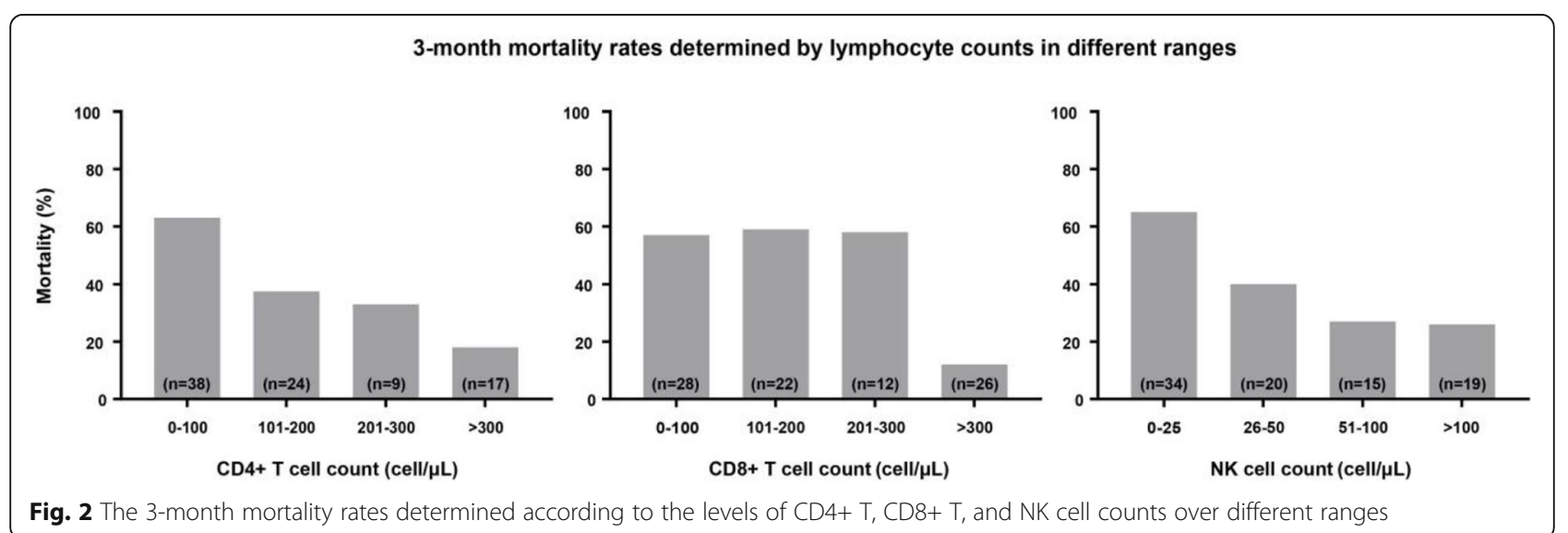

Fig. 2 The 3-month mortality rates determined according to the levels of CD4+ T, CD8+ T, and NK cell counts over different ranges 


\section{Survival curve for the Cox regression model}

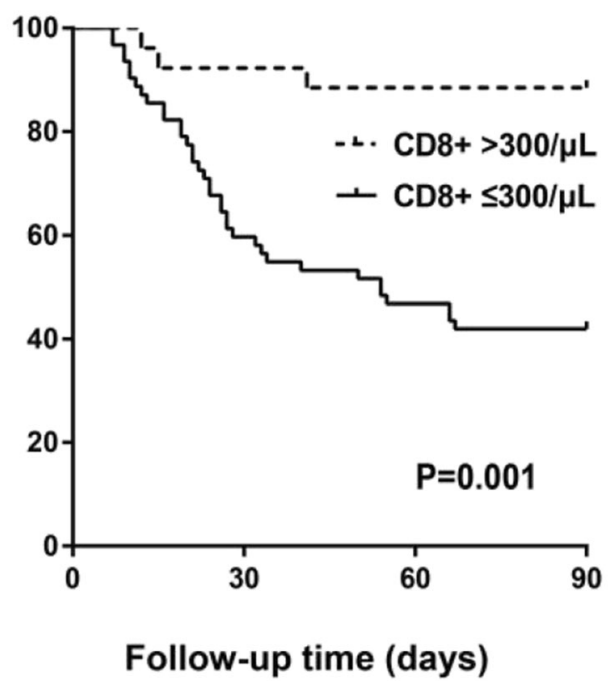

Fig. 3 Survival curve for the Cox regression hazards model for the relationship between $\mathrm{CD} 8+\mathrm{T}$ cell count and 3-month mortality

lung injury as a cost [27]. Dysregulation of CD4+ T cells can lead to a decrease in their ability to assist CD8+ T cells, which in turn leads to a reduction in the killing and dissolving function of CD8+ T cells; that is, the regulation of the immune response becomes imbalanced in the negative direction. In our study, a CD8 $+\mathrm{T}$ cell count $<300 / \mu \mathrm{L}$ was an independent risk factor for death in PCP patients. Although CD4+ T cells play a central role in coordinating host defences against $P$. jirovecii, the inhibition and cytotoxic effects of CD8+ T cells seem to be critical to control and terminate the infection.

The NK cell count was also associated with the prognosis of PCP patients. Most striking of our findings was the progressive increase in mortality as NK cell count decreased from $>100 / \mu \mathrm{L}(26 \%$ mortality) to $<25 / \mu \mathrm{L}$ (65\% mortality). NK cells play an important role in the immune defence against $P$. jirovecii infection by releasing IFN- $\gamma$, granzyme, and perforin and by their direct microbial activity $[28,29]$. Recent studies have demonstrated that NK cells directly regulate adaptive immune responses through their interaction with $\mathrm{CD} 4+\mathrm{T}$ cells [30-32]. Therefore, we believe that the NK cell count has certain prognostic value for PCP patients. Being aware of the importance of NK cells in combatting $P$. jirovecii infection, it is necessary for us to further clarify the immune process in response to $P$. jirovecii infection in humans.

We usually believe that the longer the exposure time and the higher the dose of immunosuppressive therapy, the more severe the degree of immunosuppression is. However, in our study, no association was found between the prognosis of PCP and the type of immunosuppressive regimen, the dosage, or the exposure time. The reason for this lack of correlation may be that the number of patients taking the different immunosuppressive regimens was very small, so the fact that almost all patients received high-dose immunosuppressive therapy eliminated the distinction between low and high levels of immunosuppression. The findings also imply that the prognosis of PCP patients cannot be simply reflected by their immunosuppressive therapy. Our study revealed that low CD4+ T cell, CD8+ T cell, and NK cell counts were correlated with a poor prognosis of $\mathrm{PCP}$, especially CD8+ T cell counts. Therefore, for patients receiving high-dose immunosuppressive therapy, lymphocyte subset analysis can greatly help clinicians assess the degree of immunosuppression. In some studies, CD4+ $\mathrm{T}$ cell count $<200 / \mathrm{mm}^{3}$ was taken as the indicator of a prevention strategy of PCP in HIV-negative patients, following the practice in HIV-positive patients [33]. Our study demonstrates that several patients have CD4+ $\mathrm{T}>200$ / $\mathrm{mm}^{3}$, and CD8+ T and NK cells are also associated with the prognosis of these patients. Because there are a variety of changes in the immune system in HIV-negative patients, they cannot be described by the CD4+ T cell count alone. Therefore, the CD4+ $\mathrm{T}$ cell count should not be the only indication of prophylaxis in HIVnegative patients, and the levels of CD8+ T and NK cell counts should also be considered.

For HIV-positive patients with severe PCP, a large amount of medical-based evidence has shown that CSs as an adjuvant treatment can reduce mortality [34]. However, for HIV-negative PCP patients, due to the non-specific anti-inflammatory effects and serious side effects of CSs, the application of CSs in immunocompromised individuals is still controversial [35]. Therefore, alternative treatments for HIV-negative patients with PCP need to be more specific. Recent studies have suggested that $\mathrm{CD} 4+\mathrm{CD} 25+\mathrm{T}$ cells [36] and CD40 ligand [30] seem to be helpful in the regulation of immunity to $P$. jirovecii infection. CD $4+\mathrm{CD} 25+\mathrm{T}$ cells seem to suppress proliferation and cytokine production to limit the occurrence of immune reconstitution disease [37]. CD40L+ effector memory CD4+ T cells can control the reactivation and maintain the response of NK cells through IL-2 production and can promote the secretion of chemokine ligand-10 (CXCL10) from dendritic cells [38]. In a murine experimental model, CD40 ligand [39-41] and anti-CD3 monoclonal antibody [42] have been confirmed to improve the prognosis of PCP infection. For HIVnegative patients with $\mathrm{PCP}$, in addition to extensive antifungal therapy, adjusting immune disorders and attenuating excessive inflammatory responses may be a new treatment strategy. 
There were several limitations to this study. First, it was a single-site study. Second, autoimmune diseases were the predominant underlying conditions among our study patients. Studies of HIV-negative PCP patients with other underlying disorders, such as organ transplantation, may yield different findings. Third, we only analysed the lymphocyte subsets of the patients after onset of the infection, but baseline lymphocyte subsets, which may also have an influence on mortality prediction, were unknown. A prospective study may be meaningful for further analysis. Fourth, follow-up results beyond 3 months were not available, so we do not know the long-term outcome of this patient cohort. Our study provides evidence of the correlation between lymphocyte subsets and short-term prognosis among HIV-negative PCP patients. Our findings suggest that a lower CD8+ T cell count is an independent risk factor for mortality, and in addition to effective anti-fungal therapy, treatments aimed at regulating immune function should be investigated.

\section{Conclusion}

In conclusion, the immune process of $P$. jirovecii infection in the human body is complex but important. Low $\mathrm{CD} 4+\mathrm{T}$ cell, CD8+ $\mathrm{T}$ cell and NK cell counts were related to the poor prognosis of PCP in HIV-negative patients, and a CD8 $+\mathrm{T}$ cell count below $300 / \mu \mathrm{L}$ was an independent predictor for death. Thus, we proposed that clinicians can use lymphocyte subsets to identify potential patients and make clinical decisions, such as adjusting the immunosuppressive regimen and choosing an appropriate patient monitoring level.

\section{Abbreviations}

BAL: Bronchoalveolar lavage; Cl: Confidence intervals; Ct: Cycle threshold; $\mathrm{D}(\mathrm{A}-\mathrm{a}) \mathrm{O} 2$ : Alveolar-arterial oxygen difference; FRET: Fluorescence resonance energy transfer; GMS staining: Grocott's methenamine silver staining; CXCL 10: Chemokine ligand-10; CS: Corticosteroid; HAART: Highly active antiretroviral therapy; HIV: Human immunodeficiency virus; HR: Hazard ratio; ICU: Intensive care unit; IRB: Institutional review board; IRD: Immune restoration disease; LDH: Lactate dehydrogenase; MV: Mechanical ventilation; MSG: Major surface glycoprotein; NK cells: Natural killer cells;

Ols: Opportunistic infections; OR: Odds ratio; $\mathrm{PaO} 2$ : Arterial partial pressure of oxygen; P. jirovecii: Pneumocystis jirovecii; PCR: Polymerase chain reaction; PCP: Pneumocystis peumonia; TMP/SMZ: Trimethoprim-sulfamethoxazole; $\beta D G: 1,3-\beta-D-g l u c a n$

\section{Acknowledgements}

Not applicable.

\section{Authors' contributions}

FJ and JX were responsible for study conceptualization. FJ wrote the draft manuscript. JX and HW revised the manuscript. The author(s) read and approved the final manuscript.

\section{Funding}

This research did not receive any specific grant from funding agencies in the public, commercial, or not-for-profit sectors.

\section{Availability of data and materials}

The datasets used and/or analysed during the current study are available from the corresponding author on reasonable request.

\section{Declarations}

\section{Ethics approval and consent to participate}

The present study was reviewed and approved by the Institutional Review Board (IRB) of Peking Union Medical College Hospital. The IRB waived the requirement to obtain informed consent from each patient because the study met the IRB's minimal risk waiver criteria. We declare that all methods were carried out in accordance with relevant guidelines and regulations.

\section{Consent for publication}

Not applicable.

\section{Competing interests}

The authors declare that they have no competing interests.

Received: 9 February 2021 Accepted: 26 April 2021

Published online: 14 May 2021

\section{References}

1. Kovacs JA, Masur H. Evolving health effects of Pneumocystis: one hundred years of progress in diagnosis and treatment. JAMA. 2009;301(24):2578-85. https://doi.org/10.1001/jama.2009.880.

2. Albarillo F, O'Keefe P. Opportunistic neurologic infections in patients with acquired immunodeficiency syndrome (AIDS). Curr Neurol Neurosci Rep. 2016;16(1):10. https://doi.org/10.1007/s11910-015-0603-8.

3. Tasaka S, Tokuda H. Pneumocystis jirovecii pneumonia in non-HIV-infected patients in the era of novel immunosuppressive therapies. J Infect Chemother. 2012;18(6):793-806. https://doi.org/10.1007/s10156-012-0453-0.

4. Thomas CF Jr, Limper AH. Pneumocystis pneumonia. N Engl J Med. 2004; 350(24):2487-98. https://doi.org/10.1056/NEJMra032588.

5. Mansharamani NG, Balachandran D, Vernovsky I, Garland R, Koziel H. Peripheral blood CD4 + T-lymphocyte counts during Pneumocystis carinii pneumonia in immunocompromised patients without HIV infection. Chest. 2000;118(3):712-20. https://doi.org/10.1378/chest.118.3.712.

6. Wickramasekaran RN, Jewell MP, Sorvillo F, Kuo T. The changing trends and profile of pneumocystosis mortality in the United States, 1999-2014. Mycoses. 2017;60(9):607-15. https://doi.org/10.1111/myc.12636.

7. Mori S, Sugimoto M. Pneumocystis jirovecii infection: an emerging threat to patients with rheumatoid arthritis. Rheumatology (Oxford). 2012;51(12): 2120-30. https://doi.org/10.1093/rheumatology/kes244.

8. Cillóniz C, Dominedò C, Álvarez-Martínez MJ, Moreno A, García F, Torres A, et al. Pneumocystis pneumonia in the twenty-first century: HIV-infected versus HIV-uninfected patients. Expert Rev Anti-Infect Ther. 2019;17(10):787801. https://doi.org/10.1080/14787210.2019.1671823.

9. Beck JM, Harmsen AG. Lymphocytes in host defense against Pneumocystis carinii. Semin Respir Infect. 1998;13(4):330-8.

10. Appay $V$, van Lier RA, Sallusto F, Roederer M. Phenotype and function of human T lymphocyte subsets: consensus and issues. Cytometry A. 2008; 73(11):975-83.

11. McKinley L, Logar AJ, McAllister F, Zheng M, Steele C, Kolls JK. Regulatory T cells dampen pulmonary inflammation and lung injury in an animal model of pneumocystis pneumonia. J Immunol. 2006;177(9):6215-26. https://doi. org/10.4049/jimmunol.177.9.6215.

12. Opata MM, Hollifield ML, Lund FE, Randall TD, Dunn R, Garvy BA, et al. B lymphocytes are required during the early priming of $C D 4+T$ cells for clearance of Pneumocystis infection in mice. J Immunol. 2015;195(2):611-20. https://doi.org/10.4049/jimmunol.1500112.

13. Alanio A, Hauser PM, Lagrou K, Melchers WJG, Helweg-Larsen J, Matos O, et al. ECIL guidelines for the diagnosis of Pneumocystis jirovecii pneumonia in patients with haematological malignancies and stem cell transplant recipients. J Antimicrob Chemother. 2016;71(9):2386-96. https://doi.org/10.1 093/jac/dkw156

14. Fauchier T, Hasseine L, Gari-Toussaint M, Casanova V, Marty PM, Pomares C. Detection of Pneumocystis jirovecii by quantitative PCR to differentiate colonization and pneumonia in Immunocompromised HIV-positive and HIVnegative patients. J Clin Microbiol. 2016;54(6):1487-95. https://doi.org/10.112 8/JCM.03174-15. 
15. Ali T, Kaitha S, Mahmood S, Ftesi A, Stone J, Bronze MS. Clinical use of antiTNF therapy and increased risk of infections. Drug Healthc Patient Saf. 2013; 5:79-99. https://doi.org/10.2147/DHPS.S28801.

16. Kumar SD, Krieger BP. CD4 lymphocyte counts and mortality in AIDS patients requiring mechanical ventilator support due to Pneumocystis carinii pneumonia. Chest. 1998;113(2):430-3. https://doi.org/10.1378/ chest.113.2.430.

17. Colford JM Jr, Segal M, Tabnak F, Chen M, Sun R, Tager I. Temporal trends and factors associated with survival after Pneumocystis carinii pneumonia in California, 1983-1992. Am J Epidemiol. 1997;146(2):115-27. https://doi.org/1 0.1093/oxfordjournals.aje.a009242.

18. Dworkin MS, Hanson DL, Navin TR. Survival of patients with AIDS, after diagnosis of Pneumocystis carinii pneumonia, in the United States. J Infect Dis. 2001;183(9):1409-12. https://doi.org/10.1086/319866.

19. Walzer PD, Evans HE, Copas AJ, Edwards SG, Grant AD, Miller RF. Early predictors of mortality from Pneumocystis jirovecii pneumonia in HIVinfected patients: 1985-2006. Clin Infect Dis. 2008;46(4):625-33. https://doi. org/10.1086/526778.

20. Fei MW, Kim EJ, Sant CA, Jarlsberg LG, Davis JL, Swartzman A, et al. Predicting mortality from HIV-associated Pneumocystis pneumonia at illness presentation: an observational cohort study. Thorax. 2009;64(12):1070-6. https://doi.org/10.1136/thx.2009.117846.

21. Liu CJ, Lee TF, Ruan SY, Yu CJ, Chien JY, Hsueh PR. Clinical characteristics, treatment outcomes, and prognostic factors of Pneumocystis pneumonia in non-HIV-infected patients. Infect Drug Resist. 2019;12:1457-67. https://doi. org/10.2147/IDR.S199761.

22. Khalife S, Chabé M, Gantois N, Audebert C, Pottier M, Hlais S, et al. Relationship between Pneumocystis carinii burden and the degree of host immunosuppression in an airborne transmission experimental model. J Eukaryot Microbiol. 2016;63(3):309-17. https://doi.org/10.1111/jeu.12280.

23. Freiwald T, Büttner $S$, Cheru NT, et al. CD4+ T cell lymphopenia predicts mortality from Pneumocystis pneumonia in kidney transplant patients. Clin Transpl. 2020;34(9):e13877.

24. Li Y, Ghannoum M, Deng C, Gao Y, Zhu H, Yu X, et al. Pneumocystis pneumonia in patients with inflammatory or autoimmune diseases: usefulness of lymphocyte subtyping. Int J Infect Dis. 2017;57:108-15. https:// doi.org/10.1016/j.jijid.2017.02.010.

25. Blanco JL, Garcia ME. Immune response to fungal infections. Vet Immunol Immunopathol. 2008;125(1-2):47-70. https://doi.org/10.1016/j.vetimm.2008 04.020.

26. Wright TW, Pryhuber GS, Chess PR, Wang Z, Notter RH, Gigliotti F. TNF receptor signaling contributes to chemokine secretion, inflammation, and respiratory deficits during Pneumocystis pneumonia. J Immunol. 2004; 172(4):2511-21. https://doi.org/10.4049/jimmunol.172.4.2511.

27. Gigliotti F, Wright TW. Immunopathogenesis of Pneumocystis carinii pneumonia. Expert Rev Mol Med. 2005;7(26):1-16. https://doi.org/10.1017/ S1462399405010203.

28. Park SJ, Hughes MA, Burdick M, Strieter RM, Mehrad B. Early NK cell-derived IFN-\{gamma\} is essential to host defense in neutropenic invasive aspergillosis. J Immunol. 2009;182(7):4306-12. https://doi.org/10.4049/ jimmunol.0803462.

29. Guan H, Moretto M, Bzik DJ, Gigley J, Khan IA. NK cells enhance dendritic cell response against parasite antigens via NKG2D pathway. J Immunol. 2007;179(1):590-6. https://doi.org/10.4049/jimmunol.179.1.590.

30. Noval Rivas M, Hazzan M, Weatherly K, Gaudray F, Salmon I, Braun MY. NK cell regulation of CD4 T cell-mediated graft-versus-host disease. J Immunol. 2010;184(12):6790-8. https://doi.org/10.4049/jimmunol.0902598.

31. Bihl F, Germain C, Luci C, Braud VM. Mechanisms of NK cell activation: CD4(+) T cells enter the scene. Cell Mol Life Sci. 2011;68(21):3457-67. https://doi.org/10.1007/s00018-011-0796-1.

32. Kelly MN, Zheng M, Ruan S, Kolls J, D'Souza A, Shellito JE. Memory CD4+ T cells are required for optimal NK cell effector functions against the opportunistic fungal pathogen Pneumocystis murina. J Immunol. 2013; 190(1):285-95. https://doi.org/10.4049/jimmunol.1200861.

33. Tadros S, Teichtahl AJ, Ciciriello S, Wicks IP. Pneumocystis jirovecii pneumonia in systemic autoimmune rheumatic disease: a case-control study. Semin Arthritis Rheum. 2017;46(6):804-9. https://doi.org/10.1016/j. semarthrit.2016.09.009.

34. Gagnon S, Boota AM, Fischl MA, Baier H, Kirksey OW, La Voie L. Corticosteroids as adjunctive therapy for severe Pneumocystis carinii pneumonia in the acquired immunodeficiency syndrome. A double-blind, placebo-controlled trial. N Engl J Med. 1990;323(21):1444-50. https://doi org/10.1056/NEJM199011223232103.

35. Fujikura Y, Manabe T, Kawana A, Kohno S. Adjunctive corticosteroids for Pneumocystis jirovecii pneumonia in non-HIV-infected patients: a systematic review and meta-analysis of observational studies. Tratamiento complementario con corticoides en la neumonía por Pneumocystis jirovecii en pacientes no infectados por VIH: revisión sistemática y metanálisis de los estudios observacionales. Arch Bronconeumol. 2017;53(2):55-61. https://doi. org/10.1016/j.arbres.2016.06.016.

36. Kelly MN, Shellito JE. Current understanding of Pneumocystis immunology. Future Microbiol. 2010;5(1):43-65. https://doi.org/10.2217/fmb.09.116.

37. Hori S, Carvalho TL, Demengeot J. CD25+CD4+ regulatory T cells suppress CD4+ T cell-mediated pulmonary hyperinflammation driven by Pneumocystis carinii in immunodeficient mice. Eur J Immunol. 2002;32(5): 1282-91. https://doi.org/10.1002/1521-4141(200205)32:5<1282::AID-IMMU12 82>3.0.CO;2-\#

38. Shimizu K, Asakura M, Fujii S. Prolonged antitumor NK cell reactivity elicited by CXCL10-expressing dendritic cells licensed by CD40L+ CD4+ memory $T$ cells. J Immunol. 2011;186(10):5927-37. https://doi.org/10.4049/jimmunol.1 003351.

39. Oz HS, Hughes WT, Rehg JE, Thomas EK. Effect of CD40 ligand and other immunomodulators on Pneumocystis carinii infection in rat model. Microb Pathog. 2000;29(3):187-90. https://doi.org/10.1006/mpat.2000.0374.

40. Wiley JA, Harmsen AG. CD40 ligand is required for resolution of Pneumocystis carinii pneumonia in mice. J Immunol. 1995;155(7):3525-9.

41. Zheng M, Shellito JE, Marrero L, Zhong Q, Julian S, Ye P, et al. CD4+ T cellindependent vaccination against Pneumocystis carinii in mice. J Clin Invest. 2001;108(10):1469-74. https://doi.org/10.1172/JCl13826.

42. Bhagwat SP, Wright TW, Gigliotti F. Anti-CD3 antibody decreases inflammation and improves outcome in a murine model of Pneumocystis pneumonia. J Immunol. 2010;184(1):497-502. https://doi.org/10.4049/ jimmunol.0901864.

\section{Publisher's Note}

Springer Nature remains neutral with regard to jurisdictional claims in published maps and institutional affiliations.

Ready to submit your research? Choose BMC and benefit from

- fast, convenient online submission

- thorough peer review by experienced researchers in your field

- rapid publication on acceptance

- support for research data, including large and complex data types

- gold Open Access which fosters wider collaboration and increased citations

- maximum visibility for your research: over $100 \mathrm{M}$ website views per year

At BMC, research is always in progress.

Learn more biomedcentral.com/submissions 